\title{
HUBUNGAN PRAKTEK PEMBERIAN MP-ASI DINI DI KELUARGA DENGAN PERTUMBUHAN DAN PERKEMBANGAN PADA ANAK DIBAWAH USIA 3 TAHUN DI WILAYAH KERJA PUSKESMAS SAWAH LEBAR KOTA BENGKULU TAHUN 2012
}

\author{
Nella Malini, Elly Wahyuni \\ Jurusan Kebidanan Poltekkes Kemenkes Bengkulu Jl. Indragiri No.3 Bengkulu \\ Jurusan Kebidanan Poltekkes Kemenkes Bengkulu Jl. Indragiri No.3 Bengkulu
}

\begin{abstract}
Growth and development has increased rapidly at an early age, from 0 to 5 years. This period is often referred to as the phase of the "Golden Age". Golden age is a very important time to pay attention to child development carefully in order to be detected as early as possible in case of abnormality. Impaired growth at the beginning of the baby's life was caused by malnutrition as a baby, giving complementary feeding too early or too late $(\mathrm{MOH}, 2005)$ to determine the relationship of giving early complementary feeding with growth and development in children under 3 years of age. The study design used in this study is the Survey Analytics, using a "Crosssectional" where research is used to examine the relationship giving early complementary feeding on the growth and development of toddlers by using the approach of observation research (collecting data) is done once and within the same (time point approach). The population in this study were all children under the age of 3 years working inSawah Lebar Clinic, amounting to 90 people. The sample used in this study is the total sampling, sampling method is a door to door.The result showed that the majority of mothers giving complementary feeding early, almost all children have abnormal growth, more than most children have abnormal development, there is a correlation between the provision of complementary feeding with Growth Early child under 3 years of age and there is a relationship between giving the MP-ASI Early child Development under the age of 3 years. Suggestion: For health workers specially for Midwives to give education about the importance of monitoring the growth and development of toddlers because this period is often referred to as the phase of "Golden Age".
\end{abstract}

\begin{abstract}
Abstrak : Pertumbuhan dan perkembangan mengalami peningkatan yang pesat pada usia dini, yaitu dari 0 sampai 5 tahun. Masa ini sering juga disebut sebagai fase "Golden Age”. Golden age merupakan masa yang sangat penting untuk memperhatikan tumbuh kembang anak secara cermat agar sedini mungkin dapat terdeteksi apabila terjadi kelainan. Gangguan pertumbuhan pada awal masa kehidupan bayi antara lain disebabkan karena kekurangan gizi sejak bayi, pemberian MPASI terlalu dini atau terlalu lambat (Depkes, 2005) untuk mengetahui hubungan pemberian MPASI dini dengan pertumbuhan dan perkembangan pada Anak usia dibawah 3 Tahun.Desain penelitian yang digunakan pada penelitian ini adalah Survey Analitik, dengan menggunakan metode pendekatan "Cross sectional" dimana penelitian ini digunakan untuk melihat hubungan pemberian MP-ASI dini terhadap pertumbuhan dan perkembangan batita dengan menggunakan pendekatan observasi penelitian (pengumpulan data) dilakukan sekali dan dalam waktu yang bersamaan (poin time approach).Populasi dalam penelitian ini adalah semua anak berusia dibawah 3 tahun di wilayah kerja Puskesmaas Sawah Lebar yang berjumlah 90 orang. Sampel yang digunakan dalam penelitian ini yaitu total sampling, cara pengambilan sampel adalah secara door to door. Hasil penelitian didapatkan bahwa sebagian besar ibu memberikan pemberian MP-ASI dini, hampir sebagian anak memiliki pertumbuhan yang abnormal, lebih dari sebagian anak memiliki perkembangan yang abnormal, ada hubungan antara Pemberian MP-ASI Dini dengan Pertumbuhan anak di bawah usia 3 tahun dan ada hubungan antara pemberian MP-ASI Dini dengan Perkembangan Anak di bawah usia 3 tahun
\end{abstract}

Kata Kunci: MP-ASI Dini, Pertumbuhan Dan Perkembangan.

Pembangunan kesehatan adalah upaya yang dilaksanakan oleh seluruh komponen bangsa yang bertujuan umtuk meningkatkan kesadaran, kemauan dan kemampuan hidup sehat bagi setiap orang agar terwujud derajat kesehatan masyarakat yang setinggi-tingginya. Untuk meningkatkan derajat kesehatan masyarakat, Departemen 
Kesehatan pada periode 2005-2009 memprioritaskan pelayanan kesehatan ibu dan anak sebagai urutan pertama dalam pembangunan kesehatan.

Keberhasilan pembangunan suatu bangsa berkaitan erat dengan kualitas sumber Daya Manusia (SDM) yang baik. Pembentukan kualitas SDM yang optimal, baik sehat secara fisik maupun psikologis sangat bergantung dari proses tumbuh kembang anak pada usia dini sampai anak tumbuh dewasa, sehingga diperlukan derajat kesehatan yang optimal (Wulandari, 2010).

Upaya pencapaian derajat kesehatan yang optimal untuk meningkatkan mutu kehidupan bangsa, keadaan gizi yang baik merupakan salah satu unsur penting. Kekurangan gizi, terutama pada anak-anak akan menghambat proses tumbuh kembang anak. Pertumbuhan terjadi pada seseorang meliputi perubahan fisik, berpikir, berperasaan, bertingkah laku dan lain-lain, sedangkan perkembangan yang dialami seorang anak merupakan rangkaian perubahan secara teratur dari satu tahap perkembangan berikutnya, dan berlaku secara umum, missal : anak berdiri dengan satu kaki, berjingkat (berjinjit), berjalan, menaiki tangga, berlari dan seterusnya.

Pertumbuhan dan perkembangan mengalami peningkatan yang pesat pada usia dini, yaitu dari 0 sampai 5 tahun. Masa ini sering juga disebut sebagai fase "Golden Age". Golden age merupakan masa yang sangat penting untuk memperhatikan tumbuh kembang anak secara cermat agar sedini mungkin dapat terdeteksi apabila terjadi kelainan. Selain itu, penanganan kelainan yang sesuai pada masa golden age dapat meminimalisir kelainan pertumbuhan dan perkembangan anak sehingga kelainan yang bersifat permanen dapat dicegah (Nutrisiani, 2010).

Usia 0-24 bulan merupakan masa pertumbuhan dan perkembangan yang pesat, sehingga kerap diistilahkan sebagai periode emas sekaligus periode kritis. Periode emas dapat diwujudkan apabila pada masa ini bayi dan anak memperoleh asupan gizi yang sesuai untuk tumbuh kem- bang optimal. Sebaliknya apabila bayi dan anak pada masa ini tidak memperoleh makanan sesuai kebutuhan gizinya, maka periode emas akan berubah menjadi periode kritis yang akan mengganggu tumbuh kembang bayi dan anak, baik pada saat ini maupun masa selanjutnya (Nutrisiani, 2010).

Masa bayi dan anak adalah masa mereka mengalami masa pertumbuhan dan perkembangan yang cepat dan sangat penting, dimana nantinya merupakan landasan yang menentukan kualitas penerus generasi bangsa. Masa kritis anak pada usia 6-24 bulan, karena kelompok umur merupakan saat periode pertumbuhan kritis dan kegagalan tumbuh (growth failure) mulai terlihat (Amin dkk, 2004).

Soetjiningsih (1995) menyebutkan bahwa perkembangan anak meliputi perkembangan fisik, kognitif, emosi, bahasa, motorik (kasar dan halus), personal sosial dan adaptif. Pemantauan perkembangan anak berguna untuk menemukan penyimpangan/hambatan perkembangan anak sejak dini, sehingga upaya pencegahan, upaya stimulasi dan upaya penyembuhan serta upaya pemulihan dapat diberikan dengan indikasi yang jelas sedini mungkin pada masa-masa kritis tumbuh kembang anak.

Untuk mencapai tumbuh kembang yang optimal dibutuhkan zat-zat gizi yang adekuat melalui pemberian makanan yang sesuai dengan tingkat kemampuan konsumsi anak, tepat jumlah (kuantitas) dan tepat mutu (kualitas), oleh karena kekurangan maupun kelebihan zat gizi, akan menimbulkan gangguan kesehatan, status gizi maupun tumbuh kembang. Selain zat-zat gizi lain, protein sangat penting pada masa pertumbuhan terutama pada bayi dan balita (1-5 tahun). Pada masa ini proses pembentukan jaringan terjadi secara besarbesaran (Nilawati, 2006).

Pengaruh asupan zat gizi terhadap gangguan perkembangan anak menurut Brown dan Pollit (1996) melalui terlebih dahulu menurunnya status gizi. Status gizi yang kurang tersebut akan menimbulkan 
kerusakan otak, letargi, sakit, dan penurunan pertumbuhan fisik. Keempat keadaan ini akan berpengaruh terhadap perkembangan intelektual. Gangguan perkembangan yang tidak normal antara lain ditandai dengan lambatnya kematangan sel-sel syaraf, lambatnya gerakan motorik, kurangnya kecerdasan dan lambatnya respon sosial (Nilawati, 2006).

Masa pertumbuhan bayi berumur 0-6 bulan membutuhkan asupan gizi yang diperoleh melalui pemberian ASI ekslusif. Analisis situasi kondisi ibu dan anak yang menyangkut upaya peningkatan pemberian air susu ibu hingga kini masih belum menunjukkan kondisi yang menggembirakan. Menurut Depkes (2005) menyatakan gangguan pertumbuhan pada awal masa kehidupan bayi antara lain disebabkan karena kekurangan gizi sejak bayi, pemberian MPASI terlalu dini atau terlalu lambat.

MP-ASI (Makanan Pendamping Air Susu Ibu) adalah makanan atau minuman yang mengandung zat gizi, diberikan kepada bayi atau anak usia 6-24 bulan guna memenuhi kebutuhan gizi selain dari ASI dan obat-obatan (Depkes RI, 2006). MPASI ini diberikan setelah anak berusia 6 bulan karena pada masa tersebut produksi ASI semakin menurun sehingga suplai zat gizi dan ASI tidak lagi memenuhi kebutuhan gizi anak yang semakin meningkat sehingga pemberian makanan dalam bentuk pelengkap sangat dianjurkan (WHO, 2003).

Hasil Laporan Survey WHO-UNICEF dan IDAI diketahui terdapat 1.655 bayi yang pernah diberikan MP-ASI terlalu dini pada usia $<6$ bulan mengalami banyak gangguan kesehatan pada masa perkembangan, sebelum mencapai usia 10 tahun, salah satu dampak akibat diberikannya MP-ASI terlalu dini adalah menurunnya daya tahun tubuh terhadap berbagai infeksi yang umumnya menyerang anak (Afriana, 2004).

Dampak yang ditimbulkan dari pemberian MP-ASI Dini terdiri dari 2 macam, yaitu jangka panjang dan jangka pendek. Dampak jangka panjang adalah obesitas, hipertensi, faterosklerosis dan alergi. Sedangkan dampak jangka pendeknya adalah penurunan produksi ASI, anemia, diare, gastroenteritis, radang tenggorokan dan gangguan pernafasan (Krisnatuti, 2000).

Di provinsi Bengkulu pemberian makanan prelakteal mencapai $52.9 \%$, dengan jenis makanan yang diberikan pada Bayi Baru Lahir (BBL) yaitu susu formula $48,1 \%$, air putih $10,7 \%$, air gula $3,7 \%$, air tajin $3,6 \%$, air kelapa $3,7 \%$, teh manis $3,6 \%$, madu $33,3 \%$, nasi / bubur 3,6\% dan lainnya $3,7 \%$ (data cakupan ASI ekslusif di Bengkulu tahun 2010).

Di wilayah Kota Bengkulu, angka pemberian MP-ASI Dini masih sangat tinggi. Berdasarkan hasil survey awal di Puskesmas Sawah Lebar tedapat 521 bayi $(91,3 \%)$ diberikan MP-ASI dini dari seuruh bayi yang berjumlah 577 orang. Angka ini lebih tinggi dibandingkan dengan puskesmas lainnya yaitu Puskesmas Padang Serai sebanyak 220 bayi (83\%) dari seluruh bayi yang berjumlah 265 orang. Sedangkan di Puskesmas Lingkar Barat sebanyak $130(78,1 \%)$ dari 165 bayi.

\section{BAHAN DAN CARA KERJA}

Desain penelitian yang digunakan pada penelitian ini adalah Survey Analitik, dengan menggunakan metode pendekatan "Cross sectional" dimana penelitian ini digunakan untuk melihat hubungan pemberian MP-ASI Dini terhadap pertumbuhan dan perkembangan batita dengan menggunakan pendekatan observasi penelitian (pengumpulan data) dilakukan sekali dan dalam waktu yang bersamaan (poin time approach).

Populasi dalam penelitian ini adalah semua anak berusia dibawah 3 tahun di wilayah kerja Puskesmaas Sawah Lebar yang berjumlah 90 orang. Sampel yang digunakan dalam penelitian ini yaitu total sampling sebanyak 90 orang, pengambilan sampel secara door to door.

Teknik Pengumpulan data pada penelitian ini adalah data sekunder yang digunakan pada saat pengambilan data awal. 
Data primer yang dikumpulkan dengan cara melakukan pengukuran tinggi badan, berat badan dan juga melakukan pengukuran skor DDST. Serta dari wawancara diperoleh mengenai riwayat pemberian makanan pendamping ASI.

Pengolahan data dilakukan dengan analisa univariat Adalah metode statistik untuk mengetahui distribusi frekuensi masing-masing variabel yang diteliti, baik variabel independen (MP-ASI Dini) maupun variabel dependen (Pertumbuhan dan Perkembangan) dengan menggunakan presentase (\%). Sedangkan analisis bivariat adalah metode statistik untuk melihat hubungan pemberian MP-ASI dini terhadap tumbuh kembang anak dengan menggunakan uji Chi-Square $\left(\mathrm{X}^{2}\right)$. Dengan tingkat signifikan $95 \%$ dengan $\alpha 0,05 \%$. Selanjutnya data diolah dengan menggunakan perangkat computer

\section{HASIL}

\section{Analisis Univariat}

Analisis univariat dilakukan pada masing-masing variabel untuk menggambarkan distribusi frekuensi masing-masing variabel tersebut. Diperoleh data sebagai berikut :

Tabel 1. Distribusi Frekuensi Pemberian MP-ASI Dini, pertumbuhan dan perkembangan anak usia dibawah 3 tahun di Wilayah Kerja Puskesmas Sawah Lebar Bengkulu Tahun 2012.

\begin{tabular}{lcc}
\hline \multicolumn{1}{c}{ Variabel } & $\begin{array}{c}\text { Jumlah } \\
(\mathbf{f = 9 0 )}\end{array}$ & $\begin{array}{c}\text { Persentase } \\
(\boldsymbol{\%})\end{array}$ \\
\hline Pemberian MP-ASI Dini & 52 & 57,8 \\
Ya & 38 & 42,2 \\
Tidak & 36 & 40,0 \\
Pertumbuhan & 54 & 60,0 \\
Abnormal & & 55,6 \\
Normal & 50 & 44,4 \\
Perkembangan & 40 & 5 \\
Nonormal & & \\
\hline
\end{tabular}

Berdasarkan tabel di atas diketahui bahwa sebagian besar responden ibu $(57,8 \%)$ memberikan MP-ASI dini, hampir sebagian responden $(40,0 \%)$ memiliki per- tumbuhan yang abnormal dan lebih dari sebagian responden $(55,6 \%)$ memiliki perkembangan yang abnormal.

Tabel 2. Hubungan Pemberian MP-ASI Dini dengan Pertumbuhan Anak di bawah usia 3 tahun di Wilayah Kerja Puskesmas Sawah Lebar Bengkulu Tahun 2012.

\begin{tabular}{|c|c|c|c|c|c|c|}
\hline \multirow[t]{3}{*}{ MP-ASI Dini } & \multicolumn{4}{|c|}{ Pertumbuhan Anak di Bawah Usia 3 Tahun } & \multirow[t]{3}{*}{$\mathbf{P}$} & \multirow{3}{*}{$\begin{array}{l}\text { Odds Ratio } \\
\text { (Min-Max) }\end{array}$} \\
\hline & \multicolumn{2}{|c|}{ Abnormal } & \multicolumn{2}{|c|}{ Normal } & & \\
\hline & $\mathbf{F}$ & $\%$ & $\mathbf{F}$ & $\%$ & & \\
\hline $\mathrm{Ya}$ & 28 & 53,8 & 24 & 64,2 & 0,002 & 4,375 \\
\hline Tidak & 8 & 21,1 & 30 & 78,9 & & \\
\hline Jumlah & 36 & 40,0 & 54 & 60,0 & & \\
\hline
\end{tabular}

Tabel di atas dijelaskan bahwa sebagian besar responden anak $(73,1 \%)$ yang diberi MP-ASI dini memiliki pertumbuhan yang abnormal, dengan nilai $\mathrm{P}=0.002$. Hal ini berarti ada hubugan yang signifikan antara pemberian MP-ASI dini dengan pertumbuhan anak di bawah usia 3 tahun di Wilayah Kerja Puskesmas Sawah Lebar Bengkulu Tahun 2012. 
Tabel 3. Hubungan Pemberian MP-ASI Dini dengan Perkembangan Anak di Bawah Usia 3 Tahun di Wilayah Kerja Puskesmas Sawah Lebar Bengkulu Tahun 2012.

\begin{tabular}{|c|c|c|c|c|c|c|}
\hline \multirow[t]{3}{*}{ MP-ASI Dini } & \multicolumn{4}{|c|}{ Perkembangan Anak di Bawah Usia 3 Tahun } & \multirow[t]{3}{*}{$\mathbf{P}$} & \multirow{3}{*}{$\begin{array}{l}\text { Odds Ratio } \\
\text { (Min-Max) }\end{array}$} \\
\hline & \multicolumn{2}{|c|}{ Abnormal } & \multicolumn{2}{|c|}{ Normal } & & \\
\hline & $\mathbf{F}$ & $\%$ & $\mathbf{F}$ & $\%$ & & \\
\hline $\mathrm{Ya}$ & 40 & 76,9 & 12 & 23,1 & 0,000 & 9,333 \\
\hline Tidak & 10 & 26,3 & 28 & 73,7 & & \\
\hline Jumlah & 50 & 55,6 & 40 & 44,4 & & \\
\hline
\end{tabular}

Tabel di atas dijelaskan bahwa sebagian besar responden anak $(73,1 \%)$ yang diberi MP-ASI dini memiliki perkembangan yang abnormal, dengan nilai $\mathrm{p}=$ 0,000 . Hal ini berarti ada hubugan yang signifikan antara pemberian MP-ASI dini dengan perkembangan anak di bawah usia 3 tahun di Wilayah Kerja Puskesmas Sawah Lebar Bengkulu Tahun 2012.

\section{PEMBAHASAN}

Hubungan Pemberian MP-ASI Dini dengan Pertumbuhan Anak di Wilayah Kerja Puskesmas Sawah Lebar Bengkulu Tahun 2012

Hasil pengelolahan melalui tabulasi silang dari 90 orang ibu yang memiliki anak di bawah usia 3 tahun, didapat 52 orang ibu $(57,8 \%)$ yang memberikan MP-ASI dini, lebih dai sebagian memiliki anak dengan pertumbuhan yang abnormal yaitu 28 bayi $(53,8 \%)$. Masa pertumbuhan bayi berumur 0-6 bulan membutuhkan asupan gizi yang diperoleh melalui pemberian ASI ekslusif. Analisis situasi kondisi ibu dan anak yang menyangkut upaya peningkatan pemberian ASI hingga kini masih belum menunjukkan kondisi yang menggembirakan.

Menurut Depkes (2005) bahwa gangguan pertumbuhan pada awal masa kehidupan bayi antara lain disebabkan karena kekurangan gizi sejak bayi, pemberian MP-ASI terlalu dini atau terlalu lambat. Sedangkan dari 38 orang ibu $(42,2 \%)$ yang memberikan ASI eksklusif sebagian besar memiliki bayi dengan pertumbuhan yang abnormal yaitu 30 orang bayi $(78,9 \%)$, hal ini disebabkan karena banyak faktor yang mempengaruhinya baik faktor yang dapat dirubah/dimodifikasi yaitu faktor keturunan, maupun faktor yang tidak dapat di- rubah atau dimodifikasi yaitu faktor lingkungan.

Hasil analisis uji chi square menunjukkan bahwa terdapat hubungan yang bermakna antara pemberian MP-ASI dini dengan pertumbuhan anak di bawah usia 3 tahun di wilayah Puskesmas Sawah Lebar Bengkulu tahun 2012 dengan keeratan sangat erat. Pemberian MP-ASI dini dengan pertumbuhan anak di bawah usia 3 tahun mempunyai rasio prevalensi 4,375 yang berarti anak dibawah usia 3 tahun berisiko atau mempengaruhi sebanyak 4 kali untuk pertumbuhan yang normal dibandingkan dengan pemberian ASI eksklusif. Pemberian MP-ASI Dini sudah terbukti berpengaruh pada gangguan pertambahan berat bayi walaupun setelah dikontrol oleh factor lainnya. Gangguan pertambahan berat bayi akibat pengaruh pemberian MPASI Dini terjadi sejak bayi berumur 2 bulan dan berlanjut pada interval umur berikutnya (Irawati, A, 2004).

Hasil penelitian ini sejalan dengan beberapa penelitian yang menyatakan bahwa keadaan kurang gizi pada bayi dan anak disebabkan karena pemberian MP-ASI yang tidak tepat. Keadaan ini memerlukan penanganan tidak hanya dengan penyediaan pangan, tetapi dengan pendekatan yang lebih komunikatif sesuai dengan tingkat pendidikan dan kemampuan masyarakat. Selain itu umur pertama kali pemberian ASI sangat penting dalam menentukan status gizi bayi. MP-ASI dini mengakibatkan kesehatan bayi menjadi rapuh. Secara nyata hal ini terbukti dengan terjadinya gagal tumbuh (Growthy Faltering) yang harus kontinyu terjadi sejak 3 bulan sampai anak mencapai umur 18 bulan (Ansori, 2002). 
Hubungan Pemberian MP-ASI Dini dengan Perkembangan Anak di Wilayah Kerja Puskesmas Sawah Lebar Bengkulu Tahun 2012.

Hasil pengelolahan melalui tabulasi silang dari 90 orang ibu yang memiliki anak di bawah usa 3 tahun, didapat 52 orang ibu $(57,8 \%)$ yang memberikan MP-ASI dini sebagian besar memiliki anak dengan perkembangan yang abnormal yaitu 40 bayi (76,9\%), hal ini dikarenakan MP-ASI dini dan makanan preakteal akan beresiko diare dan infeksi (ISPA) pada bayi. Dengan terjadinya infeksi, tubuh akan mengalami demam sehingga kebutuhan zat gizi dan energi semakin meningkat sedangkan asupan makanan akan menurun yang berdampak pada penurunan daya tahan tubuh. Dengan pemberian MP-ASI dini maka konsumsi energi dan zat gizi dari ASI akan menurun yang berdampak pada kegagalan pertumbuhan dan perkembangan bayi dan anak (Pudjiadi, S, 1990).

Dengan ketepatan ibu memberikan makanan pendamping ASI yang bergizi dan sesuai dengan umur bayinya dan adanya peluang waktu ibu untuk memberikan perhatian dalam pemberian makanan pada bayinya serta adanya pemantauan yang sering terhadap perkembangan bayinya dengan kata lain seringnya dilakukan stimulasi perkembangan sesuai umurnya, kematangan otot dan ini sangat berpengaruh terhadap pertumbuhan kemampuan motorik kasarnya. Sedangkan dari 38 orang ibu $(42,2 \%)$ yang memberikan ASI eksklusif sebagian besar memiliki bayi dengan perkembangan tidak normal yaitu 10 orang bayi $(26,3 \%)$ hal ini memungkinkan karena MP-ASI Dini bukan salah satunya penyebab perkembangan anak yang abnormal, melainkan banyak faktor seperti faktor lingkungan dan keturunan.

Hasil analisis uji chi square menunjukkan bahwa terdapat hubungan yang bermakna antara pemberian MP-ASI dini dengan perkembangan anak di bawah usia 3 tahun di wilayah Puskesmas Sawah Lebar Bengkulu tahun 2012 dengan keeratan sangat erat dan mempunyai rasio prevalensi 9,333 yang berarti anak dibawah usia 3 tahun berisiko atau mempengaruhi sebanyak 9,333 kali untuk perkembangan yang normal dibandingkan dengan pemberian ASI eksklusif.

Pengaruh asupan zat gizi terhadap gangguan perkembangan anak menurut Brown dan Pollit (1996) melalui terlebih dahulu menurunnya status gizi. Status gizi yang kurang tersebut akan menimbulkan kerusakan otak, letargi, sakit, dan penurunan pertumbuhan fisik. Keempat keadaan ini akan berpengaruh terhadap perkembangan intelektual. Gangguan perkembangan yang tidak normal antara lain ditandai dengan lambatnya kematangan sel-sel syaraf, lambatnya gerakan motorik, kurangnya kecerdasan dan lambatnya respon sosial (Nilawati, 2006).

Beberapa penelitian menyatakan keadaan kurang gizi pada bayi dan anak disebabkan karena pemberian MP-ASI yang tidak tepat, keadaan ini memerlukan penanganan tidak hanya dengan penyediaan pangan, tetapi dengan pendekatan yang lebih komunikatif sesuai dengan tingkat pendidikan dan penurunan daya tahan tubuh. Dengan pemberian MP-ASI Dini maka konsumsi energy dan zat gizi dari ASI akan menurun yang berdampak pada kegagalan pertumbuhan bayi dan anak ( Pudjiadi, S, 1990 ).

Penelitian ini sejalan dengan teori Moehji (2005) menyatakan banyak hal yang mempengaruhi aspek perkembangan motorik kasar dan fisik anak (ukuran tubuh. kaki, tangan dan anggota badan lainnya yang langsung berhubungan dengan gerak anak) dan otak yang merupakan kemudi utama dari semua gerak motorik maupun halus. kedua faktor utama tersebut perkembangannya tergantung pada aspek genetis/keturunan dan asupan gizi yang diterima anak pada masa pertumbuhannya secara langsung.

\section{KESIMPULAN}

Dari hasil penelitian yang dilakukan tanggal 6 Juli sampai dengan tanggal 6 Agustus 2012 mengenai Pertumbuhan dan Perkembangan Anak dan Pemberian MP- 
ASI Dini didapatkan hasil : lebih dari sebagian ibu memberikan pemberian MPASI dini, hampir sebagian anak memiliki pertumbuhan yang abnormal, lebih dari sebagian anak memiliki perkembangan yang

\section{DAFTAR KEPUSTAKAAN}

Arikunto, (2002). Penelitian Suatu Pendekatan Praktek. Jakarta : Rineka Cipta.

Aritonang, (1996). Pemantauan Pertumbuhan Balita. Yogyakarta : Kanisius.

Arixs, (2005). Bayi Perlu Asi Exslusif Selama 6 Bulan. (diakses tanggal 16 April 2009), di unduh dari :http://www.tumbang.com/.

Depkes RI, (2005). Pedoman Pelaksanaan Stimulasi, Deteksi dan Intervensi Dini Tumbuh Kembang Anak Di Tingkat Pelayanan Kesehatan Dasar. Jakarta : Depkes RI.

(2006)_ Pedoman Pengelolaan Makan Pendamping. Jakarta : Depkes RI. (2006). SUSESNAS. Jakarta: Depkes RI. (2008). Manajemen Terpadu Balita Sakit. Jakarta : Depkes RI.

Dinkes Propinsi Bengkulu, (2011). Profil Kesehatan Kota Bengkulu Tahun 2011: Dinas Kota Bengkulu.

Krisnatuti, (2008). Menyiapkan Makanan Pendamping ASI. Jakarta : Puspa Swara.

Moehji, (2005). Faktor-faktor Yang berhubngan Dengan Pemberian Makanan Pendamping ASI (MP-ASI) Pada Bayi O 24 Bulan. (diakses tanggal 22 Mei 2009) di unduh dari :http://www.anak sehat.com/. abnormal, ada hubungan antara Pemberian MP-ASI Dini dengan Pertumbuhan Anak di bawah usia 3 tahun dan ada hubungan antara Pemberian MP-ASI Dini dengan Perkembangan Anak di bawah usia 3 tahun

Nelson, (2002). Ilmu Kesehatan Anak. Jakarta : EGC.

Notoatmodjo, 2010. Metodelogi Penelitian Kesehatan. Jakarta: Rineka Cipta.

Paula, MD, (2001). Bayi Anda Tahun Pertama. Jakarta : Arcan.

Rusmil, (2006). Pertumbuhan dan Perkembangan Anak. (diakses tanggal 03 Mei 2009) di unduh dari :http://www.int/ raihaniah Aqila Putri Rachdian.com/.

Steven P. Shelov.2004. Perawatan Untuk Bayi Dan Balita. Jakarta: Arcan.

Suherman, (2002). Buku Perkembangan Anak. Jakarta : EGC.

Sugiyono, (2008). Metode Penelitian Administratif. Bandung : Alfabeta.

Soetjiningsih, (1995). Tumbuh Kembang Anak. Jakarta : EGC.

Thaha AR, (2006). Makanan Pendamping ASI Berbasis Masyarakat. (diakses tanggal 22Mei2009), diunduhdari http://www.int/nutrition/publications/infanfee ding.com/.

WHO, (2003). Implementing The Global Strategy For Infun and Young Child Feeding. (diakses tanggal 25 Mei 2009) di unduh dari :http://www.who.int.org. 